\title{
Aspect Markers in Hmar
}

\section{Elangbam Sharatkumar Singh, Ph.D.}

\begin{abstract}
This paper attempts to highlight the aspect markers in Hmar. Hmar is a Tibeto-Burman language spoken by the Hmar people. They are mainly concentrated in Churachandpur district, the southern part of Manipur. And other villages outside Manipur are also scattered over a vast area comprising of northern Mizoram, Cachar district of Assam and Chittangong hill tracts of Bangladesh.

Hmar is one of the recognized tribes of Manipur. It is regarded one of the nuclei of the Central Chin sub-group of Kuki-Chin group of Tibeto-Burman family (Grierson, LSI Vol. III, part III, 1904).

There are four aspect markers in Hmar. They are - simple aspect, progressive aspect, perfective aspect and unrealized or non realization aspect. Simple aspect is marked by 'zero markers', progressive aspect is denoted by /jï/ or /mek/ and /lai/. The progressive aspect markers/jiy/ or /mek/ can be used separately. Again, the progressive aspect marker /lail can be used with a progressive aspect marker either /jin/ or /mek/ in progressive sentences, perfective aspect is expressed by $/ t^{h} k^{h} a /$ and unrealized or non realization aspect marker is denoted by /tih/ or /dip/.
\end{abstract}

Keywords: progressive aspect, perfective aspect, simple aspect, unrealized aspect

\section{Introduction}

Aspects are different ways of viewing the internal temporal constituency of a situation (Comrie, 1976). Four types of aspects can be established in Hmar. These aspects have different aspect markers. Aspects in Hmar can be made by suffixing aspect markers to the verb root of the sentence. These aspect markers can stand at the end part of a sentence. In the case of simple aspect, the marker is denoted by zero markers. They are discussed as below:

1.) Simple aspect,

2.) Progressive aspect,

3.) Perfect aspect and

4.) Unrealized or Non realization aspect.

\section{SIMPLE ASPECT}

Simple aspect expresses simple statement, habitual fact and universal truth. It is formed by suffixing zero ( ) markers to the verb roots. Here, in the examples ( $1,2 \& 3$ both singular and plural) the ' marker' can be suffixed to the verb root ' $p$ hak' means 'to eat'. The first person plural pronouns /kəi-ni/ expresses 'exclusive' whereas /əai-ni/ expresses 'inclusive' of the subject/speaker as in examples (1a. \& 1.b) as follows:
(1.) $/ \mathrm{k} \partial \mathrm{i}$ bu $\mathrm{p}^{\mathrm{h}} \mathrm{ak} \quad /$
1PP. rice eat S.ASP.
'I eat rice.'
(1.a) /kəi - ni bu p pak /
1 PP. PL. rice eat S.ASP.
'We (EXCL.) eat rice.'
(1.b) /ai - ni bu phak /
1PP. PL. rice eat S.ASP.
'We (INCL.) eat rice.'
(2.) /nəy bu $\mathrm{p}^{\mathrm{h}}$ ak /
2PP. rice eat S.ASP.
/nəy - ni bu phak /
'You (SG.) eat rice.'
(3.) /oma bu $\mathrm{p}^{\mathrm{h}} \mathrm{ak} /$
3PP. rice eat S.ASP.
2PP. PL. rice eat S.ASP.
'You (PL.) eat rice.'
(3.a) /əma- ni bu p pak /
3PP. PL. rice eat S.ASP.
'She/he eats rice.'
'They eat rice.'

In Hmar, the subject can be is omitted and it is denoted by the pronominal markers like - /kə/, /i/, and /ə/ in the singular sentences. The pronominal markers - /kəi/ 'first person (I)', /nəy/ 'second person (you)' and /əma/ '(she/he)' are used for singular pronouns whereas / $\mathrm{kən} / \mathrm{or} / ə \mathrm{i} /$, /in/ and /ən/ in the plural counterparts. The second person pronominal marker /i// is different form of second personal pronoun /nəy/. It is different to compare with first person and third person pronominal markers and its' plural counterpart is /in/ as in the examples (5. \& 5a.). Such pronominal markers are prefixed to the verb roots (except in the case of unrealized aspect marker 'tih'). Examples are as below:

(4.) / bu kə- $\mathrm{p}^{\mathrm{h} a k}$ / (4.a) / bu kən- $\mathrm{p}^{\mathrm{h}} \mathrm{ak}$ / 
rice 1PRO. eat S.ASP.

'I eat rice.'
(5.) / bu i- $\mathrm{p}^{\mathrm{h}} \mathrm{ak}$ /
rice 2PRO. eat S.ASP.
'You (SG.) eat rice.'
(6.) / bu $2-\mathrm{p}^{\mathrm{h}} \mathrm{ak} \quad /$
rice 3PRO. eat S.ASP.
'He eats rice.'

rice 1PRO. eat S.ASP.

'We (EXCL.) eat rice.'

(4.b) / bu oi- p ${ }^{\mathrm{h}} \mathrm{ak} \quad /$

rice $1 P P$. eat S.ASP.

'We (INCL.) eat rice.'

(5.a) / bu in- $\mathrm{p}^{\mathrm{h}} \mathrm{ak}$ /

rice 2PRO. eat S.ASP.

'You (PL.) eat rice.'

(6.a) / bu on- $\mathrm{p}^{\mathrm{h}}$ ak /

rice 3PRO. eat S.ASP.

'They eat rice.'

\section{PROGRESSIVE ASPECT}

Progressive aspect expresses the action which is going on but not completed. It is denoted by suffix markers /-mek/ and /-jin/. The suffix markers /-mek/ or /-jin/ is suffixed to the verb root to express the action which is not completed.

\section{Examples of /-mek/:}

/kəi tui don- mek/

1PP. water drink PROG.

'I am drinking water.'

(8.)

/nəy tui don- mek/

2PP. water drink PROG.

'You (SG.) are drinking water.'

(9.) /oma tui don- mek/

3PP.water drink PROG.

'She/he is drinking water.'

(7.a)

The progressive aspect marker /jin/ carries the same meaning of /mek/. It is also suffixed to the verb roots to express progressive aspect. It is given in the examples:

\section{Examples of /-jin/:}

$$
\begin{aligned}
& \text { /kəi tui don- jiy/ } \\
& \text { 1PP.water drink PROG. } \\
& \text { 'I am drinking water.' }
\end{aligned}
$$

(11.) /nəy tui don- jiy/ 2PP.water drink PROG.

'You (SG.) are drinking water.'

(12.) /oma tui don- jin/

3PP.water drink PROG.

'She/he is drinking water.' (10.a)

Another progressive aspect marker /lai/ can occur with /-mek/ or /-jin/ to form progressive aspect in the examples $(13,14 \& 15)$. In this type of sentence, two progressive aspect markers can be used.

\section{Examples of progressive marker /lai/ with /mek/:}

$$
\begin{aligned}
& \text { /kəi tui don- lai- mek/ } \\
& \text { 1PP. water drink PROG. PROG. } \\
& \text { 'I am drinking water.' }
\end{aligned}
$$

/kəi-ni tui don- mek/

1PP.PL.water drink PROG.

'We (EXCL.) are drinking water.'

/əi-ni tui don-mek/

1PP.PL.water drink PROG.

'We (INCL.) are drinking water.'

/nəy - ni tui don- mek/

2PP. PL. water drink PROG.

'You (PL.) are drinking water.'

/əma- ni tui don- mek/

3PP. PL. water drink PROG.

'They are drinking water.' 
2PP. water drink PROG. PROG.

'You (SG.) are drinking water.'

(14.)

/əma tui don- lai- mek/

3PP.water drink PROG. PROG.

'She/he is drinking water.'
2PP. PL. water drink PROG. PROG.

'You (PL.) are drinking water.'

(14.a) /əma- ni tui don- lai- mek/

3PP. PL. water drink PROG. PROG.

'They are drinking water.'

The aspect marker /jin/ is added to the verb root just after the aspect marker /lai/. In this type, two progressive aspect markers can be used.

Examples of progressive marker /lai/ with /-jin/:

/kəi tui don- lai- jin/

1PP. water drink PROG. PROG.

'I am drinking water.'

$$
\begin{aligned}
& \text { /nəy tui don- lai- jin/ } \\
& \text { 2PP.water drink PROG. PROG. } \\
& \text { 'You (SG.) are drinking water.' } \\
& \text { /əma tui don- lai- jin/ } \\
& \text { 3PP.water drink PROG. PROG. } \\
& \text { 'She/he is drinking water.' }
\end{aligned}
$$

\section{PERFECTIVE ASPECT}

Perfective aspect expresses an action which has already completed. It is denoted by the suffix marker $/ \mathbf{t a k}^{\mathbf{h}} \mathbf{a} /$. This suffix marker $/ \operatorname{tak}^{\mathrm{h}} \mathrm{a} /$ is suffixed to the verb root. The verb root 'don' means 'drink' is made perfective aspect by suffixing $/ \operatorname{tak}^{\mathrm{h}} \mathrm{a} /$ as in the following examples (18, 18.a, 18.b, 19.,19.a, 20 and 20.a).

$$
\begin{aligned}
& \text { /kəi tui don- } \text { tak }^{\mathrm{h}} \mathrm{a} / \\
& \text { 1PP. water drink PERF. } \\
& \text { 'I am drinking water.' }
\end{aligned}
$$

$$
\begin{aligned}
& \text { /nəy tui don- } \operatorname{tak}^{\mathrm{h}} \mathrm{a} / \\
& \text { 2PP. water drink PERF. } \\
& \text { 'You (SG.) are drinking water.' } \\
& \text { /əma tui don- tak } \mathrm{h}^{\mathrm{h}} \text { / } \\
& \text { 3PP.water drink PERF. } \\
& \text { 'She/he is drinking water.' }
\end{aligned}
$$

/kəi-ni tui don- $\operatorname{tak}^{\mathrm{h}} \mathrm{a} /$

1PP.PL.water drink PERF.

'We (EXCL.) are drinking water.'

/əi-ni tui don- tak ${ }^{\mathrm{h}} \mathrm{a} /$

1PP.PL.water drink PERF.

'We (INCL.) are drinking water.'

(19.a) /nəy -ni tui don- $\operatorname{tak}^{\mathrm{h}} \mathrm{a} /$

3PP.PL. water drink PERF.

'You (PL.) are drinking water.'

(20.a) /oma- ni tui don- $\operatorname{tak}^{\mathrm{h}} \mathrm{a} /$

3PP. PL. water drink PERF.

'They are drinking water.'

\section{UNREALIZED OR NON-REALIZATION ASPECT}

Unrealized or non-realization aspect expresses that the action is yet to be performed or it is not yet realized which may not performed at all. It is also known as irrealis aspect. There are two types of unrealized aspect markers, they are - /- $\mathbf{d i n} /$ and /- tih/. The aspect marker/- din/ is suffixed to the verb roots whereas the aspect marker /- tih/ is suffixed to the pronominal markers. Both the aspect markers /- din/ and /- tih/ can stand at the final position of the sentences.

\section{Examples of /din/:}

(21.) /kəi jin hmuy- din/

1PP.tomorrow come UNR.

'I will come tomorrow.' (21.a) /kəi-ni jin hmuy-din /

1PP.PL. tomorrow come UNR.

'We (EXCL.) will come tomorrow.'

/əi-ni jin hmun- din/

1PP.PL. tomorrow come UNR.

'We (INCL.) will come yesterday.' 
(22.) /nəy jin hmuy- din /

2PP. tomorrow come UNR.

'You (SG.) will come tomorrow.'

(23.) /əma jin hmuy-din/

3PP.tomorrow come UNR.

'She/he will come tomorrow.' (22.a) /nəy-ni jin hmuy- din /

2PP.PL. tomorrow come UNR.

'You (PL.) will come tomorrow.'

/əma-ni jin hmuy- diy/

3PP. PL. tomorrow come UNR.

'They will come tomorrow.'

\section{Examples of /tih/:}

$$
\begin{aligned}
& \text { / jin hmun kə- tih/ } \\
& \text { tomorrow come 1PRO. UNR. }
\end{aligned}
$$

'I will come tomorrow.'

/nəy jin hmun i- tih/

you tomorrow come 2PRO.UNR.

'You (SG.) will come tomorrow.'

(26.) /əma jin hmu - $^{- \text {tih/ }}$

She/he tomorrowcome 3PRO.UNR.

'She/he will come tomorrow.'

$$
\begin{aligned}
& \text { tomorrow come 1PRO. UNR. } \\
& \text { 'We (INCL.) will come tomorrow.' } \\
& \text { (25.a) /nəy-ni jin hmun in- tih / } \\
& \text { you PL. tomorrow come 2PRO.UNR. } \\
& \text { 'You (PL.) will come tomorrow.' } \\
& \text { (26.a) / ma-ni jin hmu on- tih/ } \\
& \text { 3PP.PL. tomorrow come 3PRO. UNR. } \\
& \text { 'They will come tomorrow.' }
\end{aligned}
$$

In the above analysis, it can be obtained that Hmar have different forms of sentences. They are - (i) sentences begin with subject (i.e. pronouns), (ii) sentences begin with subject and pronominal markers before the verb root and, (iii) sentences made with pronominal marker before the unrealized aspect marker /tih/.

(i) Sentences begin with subject (i.e. pronoun):

In this type of sentences, the personal pronoun begins first at the sentence. The personal pronouns are /kəi/, /nəy/, and /əma/ are used as first person, second person and third person singular pronouns whereas /kəini/ or /əini/, /nəyni/ and /əmani/ used as first person, second person and third person plural pronouns respectively. Examples are as below:

(ii) Sentences begin with subject and the pronominal markers before the verb root
(27.) $/ \mathrm{k} ə \mathrm{i}$ bu p $\mathrm{p}^{\mathrm{h}} \mathrm{ak} /$
1PP. rice eat
'I eat rice.'
1PP.PL. rice eat
'We (EXCL.) eat rice.'
(27.b) /əi- ni bu pak/
1PP. PL. rice eat
'We (INCL.) eat rice.'
(28.) /nəy bu p pak/
(28.a) /nəy- ni bu phak/
2PP. rice eat
'You (SG.) eat rice.'
1PP.PL. rice eat
'You (PL.) eat rice.'
/oma bu $\mathrm{p}^{\mathrm{h}} \mathrm{ak} /$
/əma- ni bu p pak/
3PP. rice eat
3PP. PL. rice eat
'She/he eats rice.'
'They eat rice.'

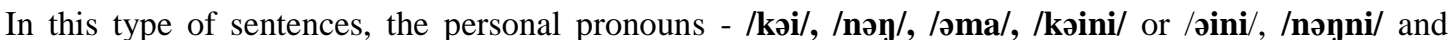
/əmani/ begins first at the sentence. The pronominal markers - /kə-/ 'I', /i-/ 'you (SG.)', /ə-/ 'she/he' are used as singular sentences whereas /kən-/ 'we (EXCL.)', or /əi//we (INCL.)', /in/, 'you' and /ən/ 'they' used as plural sentences respectively. Examples are as below:
(28.)
/kəi bu kə- $\mathrm{p}^{\mathrm{h}} \mathrm{ak} /$
$1 \mathrm{PP}$. rice $1 \mathrm{PRO}$. eat
(28.a) /kəi- ni bu kən- $\mathrm{p}^{\mathrm{h}} \mathrm{ak}$
1PP.PL. rice 1PRO. eat
'I eat rice.'
'We (EXCL.) eat rice.'
(28.b) /əi- ni bu əi- $\mathrm{p}^{\mathrm{h}} \mathrm{ak} /$
1PP. PL. rice 1 PRO. eat 
(29.)

$$
\begin{aligned}
& \text { /nəy bu i- } \mathrm{p}^{\mathrm{h}} \text { ak/ } \\
& \text { 2PP. rice 2PRO. eat } \\
& \text { 'You (SG.) eat rice.' } \\
& \text { /əma bu ə- } \mathrm{p}^{\mathrm{h}} \text { ak/ } \\
& \text { 3PP. rice 3PRO. eat } \\
& \text { 'She/he eats rice.' }
\end{aligned}
$$

'We (INCL.) eat rice.'

(29.a) /nən- ni bu in- $\mathrm{p}^{\mathrm{h}}$ ak/

1PP.PL. rice 2PRO. eat

'You (PL.) eat rice.'

(30.a) /əma- ni bu ən- $\mathrm{p}^{\mathrm{h}} \mathrm{ak} /$

3PP. PL. rice 3PRO. eat

'They eat rice.'

(iii) Sentences made with pronominal markers before the unrealized aspect marker /tih/:

In this type of sentence, the pronominal markers can stand just before the unrealized aspect marker /tih/. In this type, the subject is denoted by pronominal markers in the middle part of sentence. Examples as:

$$
\begin{aligned}
& \text { / bu } \mathrm{p}^{\mathrm{h}} \text { ak kə- tih/ } \\
& \text { rice eat } 1 \mathrm{PRO} \text {. UNR. } \\
& \text { 'I shall eat rice.' }
\end{aligned}
$$

$$
\begin{aligned}
& \text { / bu } \mathrm{p}^{\mathrm{h}} \text { ak i- tih/ } \\
& \text { rice eat 2PRO. UNR. } \\
& \text { 'You (SG.) will eat rice.' } \\
& \text { / bu p pak ə- tih/ } \\
& \text { rice eat 3PRO. UNR. } \\
& \text { 'She/he will eat rice.' }
\end{aligned}
$$

\section{CONCLUSION}

In the above analysis, it is found that simple aspect is marked by 'zero markers', progressive aspect is denoted by /jin/ or / $\mathbf{m e k} /$ and /lai/, perfective aspect is denoted by $/ \mathbf{t a k} \mathbf{k}^{\mathbf{h}} \mathbf{a} /$ and unrealized or non realization aspect is expressed by /tih/ or /din/.

The subject of the sentence is sometimes omitted. It is denoted by pronominal markers. Three distinctive features of pronoun- $/ \mathbf{k} \boldsymbol{i} / /, / \mathbf{n} \mathbf{~} /$, and /əma/ are used as first person, second person and third person singular pronouns, and /kəini/ or /əini/, /nəyni/ and /əmani/ used as first person, second person and third person

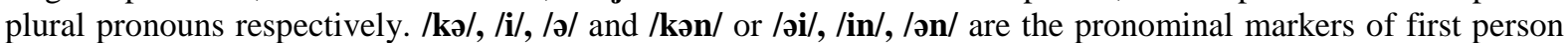
singular and plural pronouns respectively. The first person pronoun /kəini/ expresses the exclusive meaning whereas /oini/ expresses the inclusive meaning of subject 'we' in a sentence.

The progressive marker markers /jiy/or/mek/ can stand separately on the other hand, the aspect marker /lai/ can make progressive aspect either /jin/ or /mek/ aspect markers in sentences.

\footnotetext{
$1 \mathrm{PP}$.

1 PRO.

2PP.

2PRO.

3PP.

3PRO.

EXCL.

INCL.

PERF.

PL.

PROG.

S.ASP.

SG.

UNR.
}

\section{Abbreviation}

'first person'
'first person pronominal marker'
'second person'
'second person pronominal marker'
'third person'
'third person pronominal marker'
'exclusive'
'inclusive'
'perfective aspect'
'plural'
'progressive aspect'
'simple aspect'
'singular'
'unrealized aspect'
'simple aspect'

\section{Reference}

[1]. Grierson, G.A. Linguistics Survey of India, Vol. III. Part III. Calcutta Reprinted 1967, Motilal Banarasidas, Delhi, 1904

[2]. Shobhana, L. C. A Grammar of Meithei. Mouton de Gruyter, Berlin, New York, 1997. 
[3]. Comrie, Bernard Aspect, Cambridge University Press, United Kingdom, 1976 